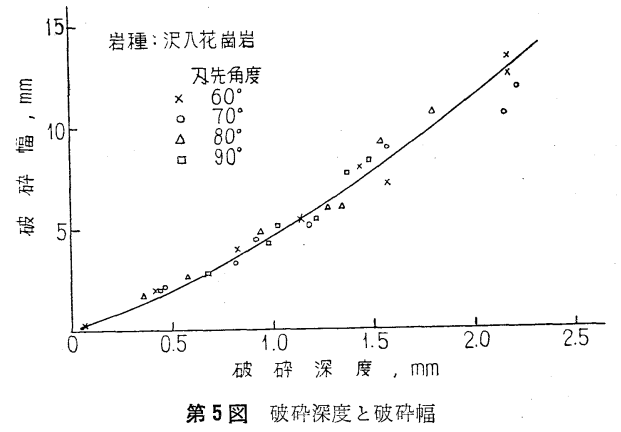

その結果は第 3 図に示すように，各押付力に対して，刃 先角度の小さいディスクカッタは大きいるのより転がり 抵抗が犬きく，同一刃先角度に沶いては押付力の増加々 そもに転がり抵抗も增大して抢り，その傾向は押付力と 破砕深度の関係之類似したものとなつた。

\section{3 破研深度とディスクカッタの䎐がり抵抗}

$5 ・ 1 ， 5 \cdot 2 か ら$ 推察されるよ5に転がり抵抗は破砕深度 の影響を受けていることは明らかであり,かつ実際の掘 さくに打いて必要とされる動力の大半は掘さく軸の回転 動力で岁るので掘さく速度を示す破砕深度と転がり抵抗 との関係を求めた。その一例は第 4 図のよ5になる。す なわち, 各破砕深度に対して, ディスクカッタの刃先角
度の大きい方が小さいものより転がり抵抗が大きく, 同 一角度に揖いては破砕深度が大きくなるとともに転がり 抵抗が増大する傾向を示した。

\section{$5 \cdot 4$ 破砕部の形状}

最後に破砕部の形状として破砕深度と破砕幅の関係を 図示すれば第 5 図のようになり，ディスクカッタの刃先 角度には関係なく，破砕深度が大きくなれば破砕幅が大 きくなることが明らかとなつた。

\section{6. 結論}

以上の各実験結果を要約すると押付力の増大により岩 石の破砕深度が増大することはもちろんでめるが，同一 の押付力に拈いても，ディスクカッタの刃先角度の小さ いものの方がより多い破砕深度を示す。ま，ディスク カッタの転がり抵抗は破砕深度に関係し, 破砕深度の増 大とともに増加するが，同一の破䃏深度に怙いては刃先 角度の小さいディスクカッタの方が転がり抵抗が小さく なつている。しかも岩石の破砕部分の形状は刃先角度に よらないことが明らかにされているので，先角度の小 さいディスクカッタを用いた方が大きい刃先角度のディ スクカッタを用いた場合に比較して, 小さい押付力, 回 転軸馬力により同一の掘さく速度を得られることが推測 される。したがつてディスクカッタの刚先形状の決定に めたつては強度扣よび摩耗等の面から許容される最小の 角度を採用することが得策でめる。

\title{
2102 岩石の切削に関する研究
}

$\begin{array}{rrrrr}\text { 東北大学工学部教授・工博 } & \text { 堀 } & \text { 部 } & \text { 富 } & \text { 男(正会員) } \\ \text { 東北大学工学部助教授・工博 } & \text { 小 } & \text { 林 } & \text { 良 } & \text { 二(正会員) } \\ \text { 東北大学工学部助手 } & \bigcirc \text { 牛 } & \text { 田 } & & \text { 稔(正会員) }\end{array}$

筆者らはさきよりメタルコアビットを用いたボーリン グの基礎的研究を行ない, 刃先の摩耗と穿孔性能々の関 係などについて考察を試みている。このようなボーリン グに扣ける回転切削機棈を詳細に解析するために，本研 究では直線切削により検討を行なつた。岩石の直線切削 に関しては從来多くの研究が行なわれているが，ビット の刃先の寸くい角が負の場合についての研究は少ないよ うに思われる。ぬた従来の直線切削に関する研究の汇々 んどは，切削方向の切削速度のみを制御できる実験装置 を用いているが，ボーリングにおける刃先の切削現象を 解析するためには刃先の押付力む自在に変兄了る実験装 置を用いねばならない。李研究では以上の目的に沿つて 油圧を利用して刃先の押付力を自由に制御できる岩石切 削装置を製作し，実験を行なつた。

この装置は第 1 図に示すように機械工作用のシエーパ に切削用へッドを取り付けたもので，油圧押付の機構は 次のようである。まず高圧の元ボンべ(1)よりパイプ連結 されてある減圧弁(2)で所要圧まで減圧し，このガスをオ イルボンベ(3の上部に導き，ボンベ内のオイルを加圧す る。ボンベ内のオイルはボンベ下部よりまカコック(4)を 通り, 高圧ゴムホースを経て切削用ヘッド(5)送られ る。三カコックは切削用ヘッドへの給排油の制御を行な う。な扮高圧ガスとしては窒素ガス，オイルは比較的粘 性の少ないサンビス た。
次に切削用ヘッドは第 2 図に示すと扣りで，ボデー上 部にピストンがあり油圧を受けてバイトホールダ取付台 を下方へ押す。取付台にはバイトホールダがピンを支点 として取り付けられ，その後部に切削抵抗測定用の鋼鉄 製ブロックがある。バイトホールダはスプリングの圧力 によつて常にブロックに押し付けられて扔り，較正もこ の状態で行なつた。またバイトホールダ下部にはチップ を固定したバイトが取り付けてある。な体研究で用い たチップはメタルコフビット用の $5 \mathrm{~mm} \times 5 \mathrm{~mm} \times 8 \mathrm{~mm}$ の

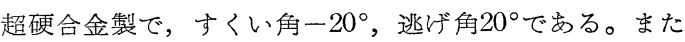
実験にあたつては，バイトホールダ取付台の下部を支え るすべり台を試料の端に取り付け，刃先が岩石試料面に ゆるい角度で接触し切削を始めるようにしてめる。

また本実験の計測は第 3 図のような計測装置を用い た。すなわち，図に示すようにバイトホールダ，切削抵 抗測定用ブロックにそれぞれ半導体ストレンゲージを 4

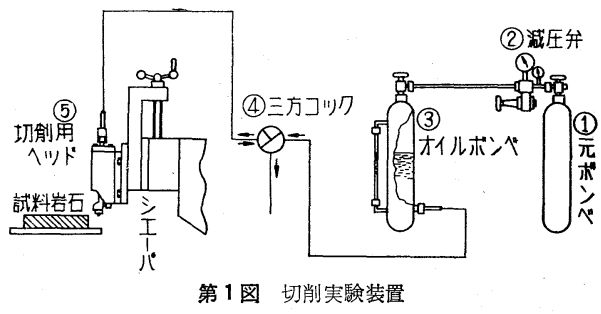

日本 鉱 業 会誌 


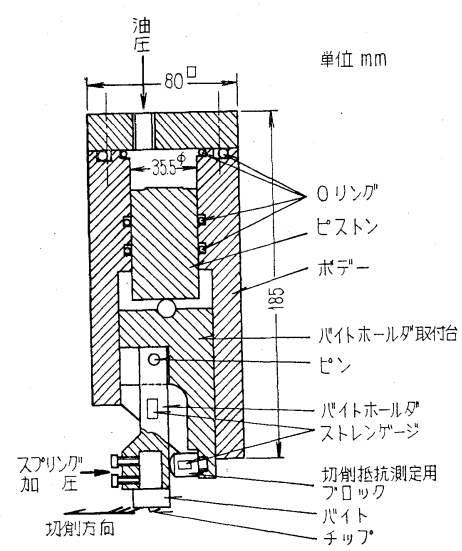

第 2 図

切削用ヘッド

枚貼り付け，ブリッジ接続とした。ちなみにバイトホー ルダのゲージ貼付部の断面は $15 \mathrm{~mm} \times 15 \mathrm{~mm}$ で, 切削抵 抗測定用ブロックの断面は $13 \mathrm{~mm} \times 13 \mathrm{~mm}$ である。この

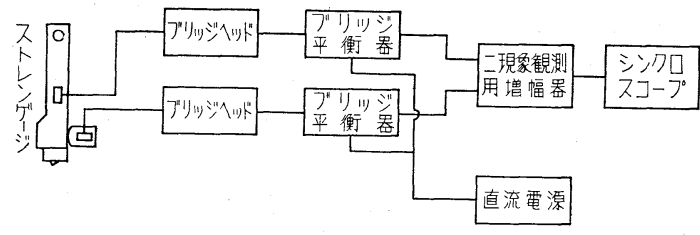

第 3 図 湘定装置

ケゲージの出力はブリッジヘッド，ブリッジ平衡器を通し て二現象観測用増幅器へ導かれ, この增幅器の出力はシ ンクロスコープヘ送られて押付力，切削抵抗が同時に観 測される。

なお岩石試料は厚さ約 $45 \mathrm{~mm}$ の板状に整形し，厚さ約 $20 \mathrm{~mm}$ の鉄板にリゴラックで貼り付けたものを用いた。 以上の切削装置ならびに測定装置を用いて，押付力と 切削抵抗々の関係，押付力，切削抵抗々切削量々の関 係, 押付力, 切削抵抗と刃先摩耗量との関係などについ て測定を行なつたので，これについて述べる。

\section{3 ぜい性材料の切削抵抗に及ぼす刃先の摩耗の影響について}

\section{1. 緒言}

鋭い刃先を有する刃物による石炭拉よびその類似物質 の切削抵抗についてはすでに報告したが，実際の刃物は チップの破損を防ぐために， $0.5 \mathrm{~mm}$ 程度の隅落しがあ らか心゙め施されているのが普通である。また最初は刃先 が鋭くとも，使用している間に摩耗して，刃先が鈍く なる。したがつて実際の切削は，汪とんどすべての場合 情，鈍い刃先を有するビットで行なわれていると考光ら れる。そしてこのような場合, 当然のことながら, 刃先 の摩耗が刃物の切味に及涪す影響はきわめて大きい。

本報では，岩石・石炭等のぜい性材料を，このような 刃先が摩耗したビットで, 切削する場合の切削抵抗関 して行なつた 2,3 の考察と実験の結果について報告す る。

\section{2. 解析的考察}

びい性材料の切削の場合には, まず刃先の圧入が起 り, 刃先付近の被切削材料が圧潰されるが，压入が進を 炕つれて, 被切削材料内の応力分布が変化し, 遂には刃 先付近から自由面までクラックが伝播し得るような応力 分布状態となつて，大きな切屑が発生する。という経過 を繰返していると考兄られる。

このような観点から, 刃先の摩耗が刃物の切削抵抗に 及洁す影響について考光てみると, 刃先の摩耗ないし鈍 化に上る切削抵抗の增加を, 刃物の压入抵抗の增加々考 える方向, 刃先付近のすくい角の変化淿るる被切削材料 内の応力分布の変化に上ると考光る方向などがあるが， ここでは刃先の摩耗した部分は, 被切削材料を圧潰して 行くだけであつて，犬きな切屑を作る上には無関係であ ると仮定した。すなおち, 摩耗した刃物の切削抵抗を, 摩耗した刃先の部分が被切削材料を圧潰して行く分と,

$\begin{array}{rrrr}\text { 東京大学工学部教嗳・工博 } & \text { 鈴 } & \text { 木 } & \text { 光(正会員) } \\ \text { 東京大学工学部助教授 } & \text { ○西 松 裕 } & \text { 一(正会員) }\end{array}$

まだ摩耗していない正常なすくい面が亀裂形ないしせん 断形の切削機棈で, 大きな切原を作って行く分の 2 つに 区別して考えて見た。

すなわら第 1 図の $\mathrm{AB}$ 面に働く切削抵抗は，すで比発 表した鋭い刃物による切削抵抗の式

$$
\left.\begin{array}{l}
P_{1}=\frac{4}{n+1} S_{t} \cdot(t-d) \cdot \frac{\sin k \cdot \cos (\alpha-\phi)}{1-\cos (k+\alpha-\phi)} \\
Q_{1}=\frac{-4}{n+1} S_{t} \cdot(t-d) \cdot \frac{\sin k \cdot \sin (\alpha-\phi)}{1-\cos (k+\alpha-\phi)}
\end{array}\right\}
$$

で表わされるとする。ただしここで

$\phi$ 二刃物すくい面と被切削材料の間の摩擦角

$$
\cot k=\frac{S_{c}{ }^{2}-16 S_{t}{ }^{2}}{8 S_{c} \cdot S_{t}}
$$

$S_{c}=$ 被切削材料の压縮強度

$S_{t}=\quad$ 引 引張強度

$n=$ 応力集中係数 $(=0.5)$

$P=$ 主切削抵接

$Q=$ 背分力(上向きをけとする)

である。

他方 B C 面に働く切削抵抗は，被切削材料の压潰抵抏

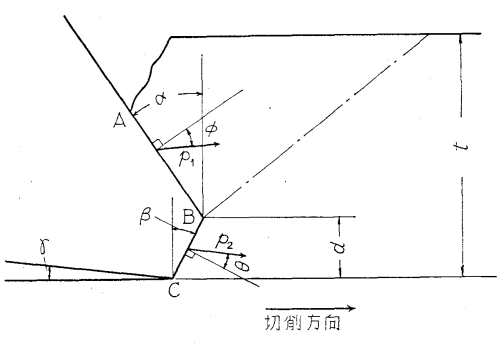

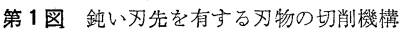

